\title{
Living Hadis as A Lifestyle (A Portrait of the Dialectics of Hadis and Culture in Indonesia)
}

\author{
Fatichatus Sa'diyah \\ Sekolah Tinggi Ilmu Ushuluddin Darussalam (STIUDA) Bangkalan \\ Email: faticha.sadiyah@gmail.com
}

\begin{abstract}
The intersection between religion and culture is one of the characteristics of Islam in Nusantara, especially in Indonesia, including a people understanding of the Hadis. In the fact, until now, the traditions of Indonesia is contain of qur' anic and hadis spirit. The result of this paper, the author considers that living sunnah is not only a learning or researching, but it has become a model of understanding of Indonesian people towards it or it's become a lifestyle of moslem in Indonesia that is always make 'hadis is live' or 'live on the sunnah.'The forms of living hadis can not be separated from the connection of hadis with the culture. This can be seen from the tradition in Indonesia such as praying for people who have died, mauludan, haul, halal bi halal, and berkatan. Some of these tradition are the character of Islam in Indonesia. As stated by dialectical theory, the hadis and the culture are two opposites thing. However, both of them can be reconciled. For example, the tradition of berkatan/ tumpengan, this tradition is an implementation of the advise of giving in Islam. So, the consequnce of the implementation of this understanding are different because it has connected with culture in Indonesia.
\end{abstract}

Keywords: Living Hadis, Islam in Indonesia, Hadis and Culture

\section{Introduction}

al-Qur'an which is referred as revelation and the word of God was conveyed to the Prophet Muhammad through Malaikat Jibril then forwarded on to mankind on earth. It is definitely right that when the Prophet Muhammad (PBUH) received the revelation, he understood and knew the purpose of the verse being revealed. Because it is not logical if the Prophet Muhammad did not know the content of the Qur'an which is revealed in the form of teachings then being forwarded and applied to humanity. Such as a letter from the lord that be delivered to the people. Before being forwarded to the people, the lordhas to know the contents first.Sometimes the lord even has to memorize what the content is and know how 
to deliver it according to the conditions and situations of the people who will receive it. If it is compared that al-Qur'an is a letter from the boss, then the Prophet Muhammad PBUH is the second person who really understands in detail on itu, so he will not cause the incorrect meaning when forwarding it to the people(Badri Khaeruman, 2010).

Besides the Qur'an, there is the hadis. In the understanding and practice, both of them can not be separated. Hadis is synonymous with sunnah. But some figures define the hadis differently from the sunnah. Ignaz Goldziher explained that the sunnah in the beginning was everything related to the traditions and habits of the ancestors. However, after Islam came, the concept of the sunnah changed as the model of the Prophet's behavior, practical norms drawn from the sayings and actions of the Prophet that were proclaimed through the Hadis(Suryadi, 2007).

Fazlur Rahman's opinion that was quoted by Suryadi explained that the sunnah is information about what the Prophet PBUH said, done, approved or not approved by him, also the same information about his friends, especially senior friends (sahabat), and more specifically about the first four Caliphs Khulafa' alRashidun). In other words, sunnah is a concept of behavior, either applied to physical actions or to mental actions, either those that occur once or that occur repeatedly(Suryadi, 2007).

There are two charasteristics contained in the hadis; 1 ) tauqifi (the contents received by revelation and expressed with the prophet's own language).2) taufiqi (that which was concluded by the prophet based on his understanding of the alQur'an).(Idris, 2017). After the Prophet's death, the Sunnah of the Prophet remained the ideal that would be followed by the early generations of Muslims afterwards by interpreting some of their new needs and new material too. This continuous and progressive interpretation is called living sunnah(Suryadi, 2007).

Sunnah which is understood as a practice that is mutually agreed (living sunnah) is actually relatively identical to the agreement (ijmak) of the people, it also includes ijtihad from the early generation of theologian(ulama) who are experts and political figures in their activities. Thus the "living sunnah" is the sunnah of the Prophet which is freely interpreted by the theologian, rulers, judges according to the situation that being faced by them(Suryadi, 2007).In addition, Living sunnah or living Hadis also means a form of study of the phenomenon of practice, tradition, ritual, or behavior that lives in a society that has its foundation on the Prophet's hadis(Zuhri, 2018).

During the spread of Islam in Java, indirectly the method of preaching(dakwah) that carried out by Walisongo to the Javanese population referred to the method of preaching(dakwah) by Rasulullah PBUH.Therefore, there is a conception that before the Javanese people concerned on the delivery and study of the Sunnah or Hadis, Walisongo had practiced the Sunnah of the 
Prophet PBUH first. Thus, the living sunnah also has existed in the Nusantara, especially in Java, during the Walisongo period or at the same time as the implementation of Islamization(A. Aziz, 2019).

Beside referring to the method of preaching by the Prophet, Walisongo also uses the tasawwuf (Islamic mysticism) approach. In a slow and gradual manner, without strongly resisting to the Javanese culture, Islam introduces tolerance and equality. In Hindu-Javanese societies which emphasize different level, Islamic teachings on equality is interesting to Javanese people. That's added the cosmopolitan merchants, the preaching of Islam then became a power to take the authotiry from the hands of Hindu-Javanese rulers (Majapahit)(D. K. Aziz, 2015).

Arab countries and Indonesia has their own characteristics that make these two countries different.(Alwi HS \& Hamid, 2020) Also about understanding hadis. Understanding hadis in Arab and Indonesia is different, because both of two countries has each characteristis. But, the Islamization process used by the Walisongo still refers to the Qur'an and the hadis and preaching method of the Prophet, but the form or body is the culture of Nusantara.

The intersection between religion and culture is one of the characteristics of Islam in Nusantara, especially in Indonesia, including a people understanding of the Hadis. In the fact, until now, the traditions of Indonesia is contain of quranic and hadis spirit. Therefore, in this paper, the author considers that living sunnah is not only a learning or researching, but it has become a model of understanding of Indonesian people towards it or it's become a lifestyle of moslem in Indonesia.

\section{Religion and Culture: An Initial Overview of the Dialectics of Hadis with Culture}

Instilling cultural values in religion that sourced from the Qur'an and Hadis are appropriate for the heterogeneity of the diversity of Muslims in Indonesia which dominated by Muslim population. al-Qur'an and Hadis become the main source of doctrine to inculcate cultural values. Cultural preachingas a series to deliver the Islamic teachings which was implemented by the Prophet PBUH became part of the historical Prophet which the Prophet got the heavy challenge and faced by the cultural community. The historical experience of the prophet's preaching in Madinahdescribed the model of cultural preachingby Muhammad in social life which was imbued with Islamic values. This is without ignoring the cultural conditions of heterogeneous societies in Madinah whichwas led by the Prophet Muhammad as prophet(Rasul) and also a preacher(Librianti, 2019). 
The entry of Islam into Java was marked by the start of the Walisongo era. Walisongo became a pioneer and spreader of Islam on the Java island(Aizid, 2016).Exactly in $1416 \mathrm{M}$ a period that took place during the reign of Demak Bintara on the north coast of Central Java(Wijaya, 2011).

The development of Islam in Java was classified as very fast, although Java had been dominated by two religions previously: local religion (animism and dynamism) and imported religion (Hindu-Buddhist). Islam even succeeded in shifting Hindu-Buddhist dominance. There are many factors that accelerate the journey of Islam in Java. Among those are the simple practice of Islam by the preachers using the theory model as practiced by Walisongo, Islam is dialogued with local culture(Wijaya, 2011).This is in line with Suparjo's explanation which says that Walisongo has a moderate attitude towards local culture. They adopted local culture and tradition, then filled them with Islamic values(Suparjo, 1970).

The response of Islam in dealing with local culture or tradition can be divided into three responses: first, accepting and developing a culture that appropriate with Islamic principles and itsuseful for the glorification of people lifes. This response is based on the consideration that those culture is useful to society; thesecond, rejectingthe tradition and cultural elements that are on contrary to the Islamic principles. This tradition is seen as endangering to the community; and thethird, let it run as usual.For examplethe habit of how Javanese people wearing a dress(Qomar, 2016).The example from the first response is the culture of offerings (sesajen) which used to drive away evil spirits before Islam come. Then when Islam came, that culture (sesajen) was developed as a treat for neighbors who came to pray for those who had died. The second, such as drinking khamr which had become a habit before the advent of Islam. Walisongo then forbade the custom in a polite manner, by using the songs of gamelan and wayang which contains religious teachings.

During the preaching in Java, Walisongo was divided into two groups; the putihan group and the abangan group. The putihan group was led by Sunan Giri and Sunan Ampel who argued that Islam must be taught same as the original teachings from the Qur'an and Hadis. Meanwhile, the abangan group was led by Sunan Kalijaga and Sunan Kudus who focused their opinions on islamization so that it could be immediately followed by all Javanese residents who were mostly 
still strong in practicing Hinduism, Buddhism, animism and dynamism. Preaching by dialogue Islam with the local culture is considered appropriate for the purpose of spreading Islam at that time. This abangan group let local tradition as they were, then filled with Islamic teachings. The implementation of this method aim to get the sympathy from the society so that they gather and they are willing to listen to the teachings of Islam conveyed. According to those preaching strategy and also the traditional Javanese beliefs, it is not surprising that Islam is easily accepted(Wijaya, 2011).

Sunan Kalijaga is a Walisongo figure who is expert at playing puppet art (wayang). His expertise in puppet art is used to do Islamic preaching activities. In each of his performances, Sunan Kalijaga does not demand a salary, but he asks the audience to follow him to say the two sentences of the creed (syahadat). The puppet themes that have been entered by Islamic values are performed as a means of teaching Islamic values to the audience, who incidentally have converted to Islam because they have uttered two sentences of the creed(D. K. Aziz, 2015).

Sunan Kudus forbids the Muslim Kudus from eating the beef.According to Abdurrahman Mas'ud quoted by Suparjo, that tradition is still maintained today even though they know it as halal food. It is done as a form of tolerance towards a culture that is united in themselves(Suparjo, 1970). The cultural creations which promoted by Walisongo always appreciate the local culture. This is was done by Walisongo to respect the local culture without eliminating the need to internalize Islamic teachings. Even giving respect for tradition is still developing today(Suparjo, 1970). Walisongo's understanding and the after generations even up to now to the religion and culture enable them to appreciate local culture and cultural sites that already exist and develop. They maintain a tolerant and inclusivetransformative attitude even though they eventually become the major community(Suparjo, 1970).

Creative dialogue between Islam and local culture does not mean sacrificing Islam and placing cultural Islam as a result of this dialogue, or as a type of Islam that is incompatible with "pure Islam", which exists and develops in the Arabian Peninsula (Jazirah Arab). Cultural Islam must be seen as a form of variant of Islam that has related dialectically to the reality in which Islam exists and develops. Becoming Islam does not have to be Arabic. Islam was born in Arabic, but not only 
for $\operatorname{Arabs}($ Librianti, 2019).The process of arabization is the opposite of indigenization (pribumisasi), through the placement of religious interpretations and their Arab cultural framework (middle east) in the reality of life in Indonesia which is multicultural- will threaten its cultural authenticity(Wasid, 2010).If Arabization is implemented, the live of the Muslims will certainly be uprooted from the roots of their local culture(Wahid, 2012). So, this arabization is not in accordance with the state of the Nusantara.

Between religion and culture each has an area of independence and also has its own symbols and values. Religion is a symbol that symbolizes the value of obedience to God. Culture has a symbol so that humans can live in it. A symbol system is needed in religion. It means, culture is important in religion. However, it needs to be distinguished between the two. Religion is final, universal, eternal and absolute. Meanwhile, culture is particular, relative and temporary. Religion without culture will indeed develop as a personal religion, but without it, religion is only as a collectivity that has no place(Librianti, 2019).Thus, the dialectic of religion and culture is a necessity. Religion gives color or spirit to culture, whereas, culture gives wealth to religion(Librianti, 2019).

In the acculturation process, local culture is used as an instrument of Islamic culture. The role of Islamic values is more to fill the substance of existing values by revising some or completely changing values that do not agree with Islamic philosophy. This was done in stages. The long history process that has made the acculturation process run well is some forms of community culture still exist, but the culture is actually a new culture because the values it carries are new values(Suparjo, 1970).

At the next level, the results of understanding Islam in Indonesia become their own color to create a cultural Islam. Cultural Islam is a phenomenon of Islamic society today which would be different from Islam in the Middle East, Europe and other regions. This is inseparable from the heterogeneity and diversity of nations which certainly do not belong to other nations. Religion contains a teaching that instills social values in its adherents, so the religious teachings constitute one of some things that forms a cultural value system. In this case, religion makes a significant contribution in the moral system and social system in society. Religious values are used as human guidelines for behavior, so that religious values are 
constructed by adherents into cultural values that are practiced in social life(Librianti, 2019).

Then, this style becomes a new discourse for Islam in Indonesia. One of them is Kh. Abdurrahman Wahid who brought up the idea of the indigenization of Islam (pribumisasi Islam)(Fitriah, 2013). The starting point of Abdurrahman's thought was not to glorify modernism, but to criticize modernism which was universalized using the knife of Islamic traditionalism. Abdurrahman did not refer directly to the Qur'an and Hadis, as is often used by modernist Islamic groups, but referred to the theory in the fiqh proposal (Ushul Fiqh) called al daruriyat al khamsah (five basic things of religion), thats are; guarding religion, guarding reason, guarding souls, guarding descent, and protecting property(Fitriah, 2013).

Likewise with the understanding of Hadis. The dialogue between religion and culture is an initial illustration of how dialogue between Hadis and culture thats found in Indonesia. As stated earlier that at the beginning of the spread of Islam carried out by Walisongo, the Living Hadis had already been enacted. It means, they preached as the Prophet preached. Although similar, but in reality not same. Remembering that the Arab culture at the periode was different from Indonesian culture when Walisongo spread the Islam. In other words, Walisongo continued to imitate the preaching of the Prophet by adjusting the situation of the Nusantara at that time.

In its development, living hadis is divided into three types. First, written tradition. Second, oral tradition. Oral tradition in living hadis actually appear along with the practice carried out by muslims. Third, the tradition of practice. This tradition in living Hadis tends to be mostly practiced by muslims. This is based on the figure of Prophet Muhammad PBUH in conveying Islamic teachings(Suryadilaga, 2007).

Generally, muslims in Indonesia do not know how and what the each arguments of their tradition. Because they carry out a tradition by imitating their ancestors. They do not know the basis of their tradition from the Qur'an or the hadis even though there is actually the argument of their tradition in the Hadis or the Qur'an. It means, they do not realize that tradition has a basis in the Qur'an and Hadis. 
Thus this living Hadis has actually become their lifestyle in understanding each teaching consciously or not.

\section{Praying For The People Who Have Died (Tahlilan)}

One of the tradition that's usually carried out by the Islamic community when there is a tragedy of death is carrying out a warning with some stages activities that are recitation of surah Yasin, Tahlil, and pray(Rodin, 2013). This event is usually held after the burial process (sometimes before the funeral), then continues every day until the seventh day. Then held again on the 40th and 100th day. Henceforth the event is held every year from the day of death of the deceased, although sometimes it varies from place to place. In the event, banquets are presented each time when the event is held. The model of serving food is usually always varied, depending on the customs that run in the place(Rodin, 2013).

If we reviewed its history, before Hinduism, Buddhism and Islam entered Indonesia, the beliefs practiced by the Indonesian people included animism. According to animist beliefs, if someone dies, the spirit (ruh) will come to his house at night to visit his family. If the house is not found in people who gather together to hold ceremonies such as burning incense and offerings to the unseen or supernatural spirits, then the spirit of the dead will be angry and enter into the bodies of the living from the family of the deceased. Therefore, at night the neighbors and friends or the community do not sleep to read spells (mantra) or just gather together(Warsino, 2017). In another source it was also stated that in the association, they did not pray for the deceased but stayed up late by playing cards/ gambling or drinking khamr(Warsino, 2017). The tradition like that was done on the first night of death, then the third, seventh, 100th night, one year, two years and the 1000th night. According to this understanding, the spirit of the dead is crucial to the happiness and accidents of those who are still alive in this world(Warsino, 2017).

As a first step, the previous ulama did not eliminate the tradition but turned it from a ceremony that was from Hindu and Buddhist into a ceremony that breathed on Islam so that, it's did not conflict with the main points of Islamic teachings. The offerings are replaced with rice and side dishes for alms (sedekah). The spells (mantra) are replaced by zikir, pray and recitation of the Qur'an. This ceremony later called tahlilan and now become the tradition and culture of most 
Indonesian people(Warsino, 2017). From this historical aspect, it can be called that the actual tahlilan event is the adoption and syncretization (assimilation) with the other religions(Rodin, 2013).

In addition, if we reviewed from the history of Islam, the tahlilan ritual event was not found in the time of the Prophet Muhammad, in the time of his friends (sahabat) and the Tabi' in and Ta $>$ bi ${ }^{\prime}$ al-Ta $>$ bi ${ }^{\prime} \mathrm{i}>\mathrm{n}$. In the fact, the program was not well known by the Ahlus Sunnah Imams such as Imam Ma>lik, Abu> $\mathrm{H}\{$ ani $>$ fah, al-Shafi'i, $\mathrm{Ah}\{\mathrm{mad}$, and other ulama who were in their time or after their time(Rodin, 2013).

Tahlilan, which was originally inherited by Walisongo is inseparable from the method of preaching that emphasizes cultural methods. Walisongo teaches the values of Islam in a flexible manner without frontal opposing Hindu tradition that have firm roots in society, but let the tradition run and only the contents are replaced with Islamic values(Warsino, 2017). Tahlilan comes from the Arabic word hallala yuhallilu (هلل يهل (هhich means to read the sentence tahlil. Then, this word was adopted by the Indonesian people for a series of activities that the author has described above.

Here are some hadis related to this tradition:

افضل الذكر لا إله إلاّ الله و افضل ما قلت انا و النبيون من قبلي لا إله الاّّ الله و هي كلمة التوحيد و الإخلاص

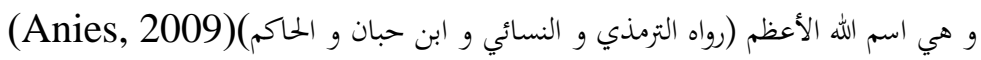

The main remembrance is la> ilah illa> Allah and the best that I and the Prophets before me was la ilaha illa> Allah. The sentence is a monotheistic sentence and Surah al-Ikhlas is the Name of the Great God. (narrated by alTurmudhi al-Nasa'i, Ibn Hibban and al-Hakim).

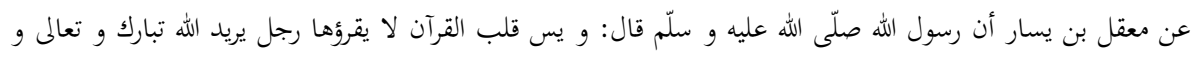

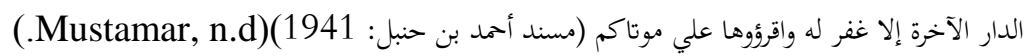

Narrated from Ma' qil bin Yasa $>r$ that the Messenger of Allah PBUH said: Yasin is the heart of the Qur'an, a man will not read it unless he will be blessed (diberkahi) by Allah and will be rewarded in the hereafter and forgiven of his sins. Read the surah to your relatives who have died. (Musnad Ah \{mad bin H\{anbal: 1941) 


\section{عن أبي هريرة رضي الله عنه قال: سمعت رسول الله صلّى الله عليه و سلّم يقول: اذا صلّيّم على الميت فأخلصوا له

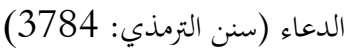

Narrated from Abi Hurayrah ra he said: I heard the Prophet Muhammad said: if you pray (mensalati) the dead, then pray for him sincerely. (Sunan atTurmudhi>:3784)

$$
\text { الصالح فن الجنة, فيقول: يا ربي الله عنه: أن رسول الله صلّى الله عليه و سلّم قال: إنّ الله عزّ و جلّ ليرفع الدرجة للعبد }
$$

Narrated by Abi Hurayrah ra, he said that the Prophet PBUH said that Allah will raise the rank of his pious servant in heaven. Then he said, "oh Allah, what do i have?" Then Allah answered, "with istighfar from your child for you."

From several hadis above, actually there is no hadis that discusses the ritual of the seventh day of death or several other days directly. However, some of the hadis above state that there are sunahs to pray for people who have died, including the recommended reading.

Some hadis above can be understood that the tradition of tahlilan (from its contain) does not conflict with the hadis of the Prophet. As the characteristics of Walisongo propaganda that uses a cultural approach, tahlilan tradition is the result of a dialectics between religion and culture in Indonesia. Thus, indirectly, Indonesian people do living Hadis.

\section{Berkatan}

In general, people who hold tahlilan provided food to be given to invited people. In a series of tahlil events, the reward of alms food is usually also intended for the arwah (Anies, 2009). In a hadis mentioned:

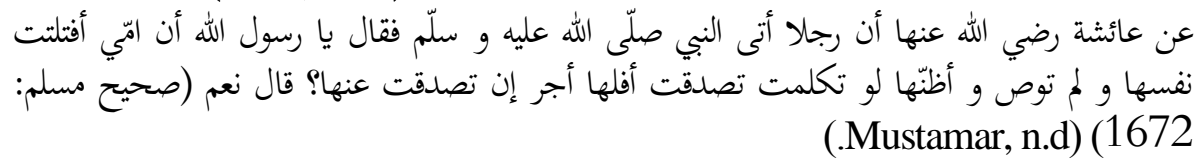

It was narrated from Aishah that the man came to the Prophet then said: $O$ Messenger of Allah, indeed my mother had died suddenly and she had not had the time to make a will (wasiat). I suspect, if she had a chance to say, she would give alms, would she get a reward if I gave alms to her? The Prophet answered, "yes" 
From these hadis it can be seen that giving alms on behalf of the deceased can be connected to the arwah. Giving the food (sedekah) is usually only served or distributed after the completion of the pray in tahlil, either to be eaten on the place or brought home. In other words, alms are given after being "blessed (diberkahi)" with pray. Food that has been blessed with pray is then called a "berkat."Berkat comes from the Arabic barakatun which means goodness which is increasing continuously. The name is based on the words of the Prophet PBUH: (Anies, 2009).

اجتمعوا على طعامكم و اذكروا اسم الله يبارك لكم فيه (رواه أحمد و ابن داوود و ابن ماجه و ابن

Gather at your banquets, and call Allah's name when you want to eat, Allah will bless you on these foods.

أثيبوا اخاكم ادعوا له بالبركة فإن الرجل اذا اكل طعامه و شرب شرابه ثمّ دعي له بالبركة فذالك ثوابه منهم.

Repay your brother's kindness in the same religion. Pray for his blessing. Indeed, someone whose food is eaten and the drink is drunk by those who are treated and then prayed for a blessing, then that pray is the kindness of those who are served.

In addition, the manifestation of various kinds of blessings is in accordance with the tradition around and the economic conditions of the compulsory owner. At present, there are blessings in the form of "ready to eat" food, some in the form of raw foods such as rice, oil, sugar, and so forth.

\section{Haul}

Haul comes from the Arabic " $\mathrm{h}\{$ awl" which means "year". The celebration of haul as is often carried out by Indonesian Muslims is the anniversary of the death. This event is usually held in a deceased or commemorated grave yard, but some are held in homes, mosques, and others. Haul is generally held right on the anniversary of the death of the deceased, which is usually classified as a person who has contributed to Islam and the Muslims during his lifetime. The tradition of haul usually lasts up to three days and three nights with a variety of events. But there are 
also those who organize it in a simple way that does not take much time with just reading tahlil and meal afterwards. The dishes that are served in the haul event are dishes that are presented for salvation (selametan) or alms from the deceased commemorated(Hanif, 2016). The purpose of the haul program is to send the reward (pahala) of reading the verses of the Qur'an and other readings. In addition to also for purposes such as tawassul, tabarruk (taking benefit), istigha $>$ thasah, and so forth (Hanif, 2016).

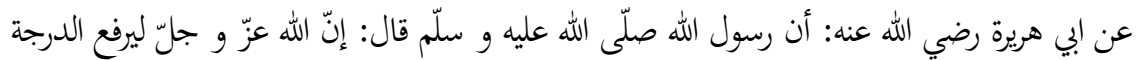

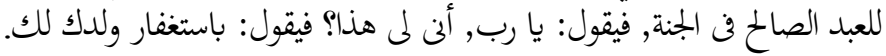

Narrated by Abi Hurayrah ra, he said that the Prophet PBUH said that Allah will raise the rank of his pious servant in heaven. Then he said, "oh Allah, what do i have?" Then Allah answered, "with istighfar from your child for you."

عن السدي بن عبيد, عن ابيه, قال: قال رجل: يا رسول الله هل بقي من برّ ابويّ شيئ أبرّهما به بعد موتما؟ قال: نعم. اربع خصال: الدعاء لمما, و الاستغفار لهما, و انقاذ عهدهما, و إكرام صديقهما, و صلة الرحم الذي لا رحم لك إلاّ من قبلهما.(UINSA, 2020)

Narrated by al-Sadi bin Abid from his father, he said: a man said: o messenger of Allah, do i still have to serve my parents after they die? The prophet replied: there are 4 things: praying for them, doing istighfar for them, keeping their promises, honoring their friends, and connecting to silaturrahim as well as the silaturrahim they continued when they were alive.

While, the main event of the haul is to commemorate the history or biography of a celebrated figure. Therefore, the momentum of haul is always waited by Muslims with the aim to emulate the life history of these figures(Hanif, 2016). Thus, haul is a religious social ritual, which is a religious ritual that is socially packaged, with a series of events that not only relate to religion directly, but various events that can enliven and attract many people to come together and pray, and get lessons together from the history of the deceased that will be presented, with the hope that lessons can be taken, especially in matters of religion, for the lives of Muslims in the future(Hanif, 2016).

Although there are some groups that do not allow the haul, but in a Hadis narrated by al-Baiha>qi> and al-Waqidi> explains that the Prophet always made 
pilgrimages (berziarah) to the tombs of martyrs (syuhada) at Uhud hill every year. When he got there he said his greetings by raising his voice (as stated in the Qur'an al-Ra'd verse 24). Which means salvation remains to you thanks to your patience, then how good your end is. Abu> Bakar also does traditions like that every year. Then 'Umar, then' Uthma $>n$. Fa $>$ t $\}$ imah also made a pilgrimage (ziarah) to the hill of Uhud and prayed. Sa'ad bin Abi> Waqqa>s\} also said hello (salam), to the martyr then he faced his friends and said, "Why don't you say hello to those who will answer your greetings?”(Hanif, 2016).

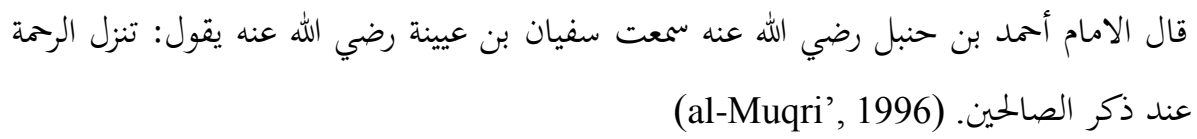

Imam Ahmad bin Hanbal ra said: $i$ hear Sufyan bin 'Uyaynah ra said: the mercy (rahmat) descends when remembering pious people.

Several hadis above explain that haul is not on contrary with hadis. From the ayat, the Prophet always made pilgrimages to the tombs of martyrs. From the last hadis explain that remembering pious people can descends the mercy.

\section{Mauludan}

Mauludan comes from the word mawlu $>\mathrm{d}$ which means birthday. The word is used with the intention of remembering the birthday of the Prophet Muhammad that coincided on the 12th Rabbi> 'al-Awwal.

أتناني جبريل فقال إنّ ربي و ربك يقول لك: تدري كيف رفعت ذكرك؟ قلت: الله أعلم. قال: لا أذكر إلاّ

ذكرت معي(Mustamar, n.d.

Jibril came to me and then said that my Lord and your Lord said to you: you know, how do I raise your zikir? Then I answered: Allah knows more. Jibril said: I will not mention except you are called with me.

The early maulid tradition was perpetuated by various Syiah Islamic caliphates such as the Fatimid Dynasty in Egypt. All the people are obliged to sing barzanii at the celebration of the Prophet's Birthday. For the caliph of this dynasty, the tradition of praise was formalized as a state tradition and as political legitimacy that this dynasty was the Islamic caliphate based on the Prophet's lineage. Sunni Muslims also celebrate the Prophet's birthday by giving praise in various areas such as Bukhara, Samarkand, Mosul, Mecca, and Damascus, but it is still held in secret so 
as not to be accused of heresy (bid'ah)(Jati, 2013).According to Marzuki Mustamar's explanation, it was only in Indonesia that the maulid celebration was held in various regions on the mass celebration.

In Indonesia, the maulid tradition is also celebrated in a variety of different ways in each region, either carried out royally or only by holding small recitals (pengajian) by reading the salawat of the Prophet. The Indonesian government itself makes the anniversary of the Prophet Muhammad PBUH as one of the national holidays. This was executed as an effort to appreciate the tradition of maulids in a country with a majority Muslim population and a majority Muslim in the world(Nadia, 2016).

For regions that based on the Islamic kingdom in Java such as Surakarta and Yogyakarta, the birthday celebration is known as the Sekaten from the word syahadatayn, which is two syahadatsentences. The Sekaten procession begins with gongso miyosthats the release of the two gamelan instruments Kyai Nogo Wilogo and Kyai Guntur Madu from their storage in the Sri Manganti Bangsal to the Ponconiti Bangsal that located in South Kemandungan (Keben) on the 5th Rabi'ul Awal which was then sounded simultaneously for 7 consecutive days up to the peak of Sekaten at 12 Rabi'ul Awal(Jati 2013').

The maulid celebration is a major celebration in Indonesian moslem society. The commemoration of this birthday is varies in each region depending on the tradition in it. There are those who commemorate the mere reading of barzanji and some who commemorate them with large-scale events as described by the writer above.

\section{Halal bi Halal}

Halal bi halal is a compound word that consists of repetition of 'halal' words, in the middle of which there is one letter (conjunctive) that is ba'(read: bi). While the term halal bi halal in the big indonesian dictionary has the meaning of forgiveness after performing Ramadan fasting which is usually held in a place by a group of people. While the meaning of halal bi halal means forgiving at the time of Eid (Zulfikar, 2018).

M. Quraish Shihab notes that the purpose of halal bihalal is to create the harmony among people. The word halal in legal perspective means the opposite or antonym of an illicit case (haram). Haram is forbidden so that the violation will 
result in sin and invite torture. While halal is something that is permissible and does not invite sin. So that, then halal bihalal can mean actions that make a person's attitude towards others who were illicit and sinful, become halal by apologizing (Zulfikar, 2018).

The essence of halal bi halal is to shake hands, apologize and eat together. The most important goal of this event is to change what is haram into halal. This tradition is usually carried out in government offices, schools on the first day after the long Eid holiday (Hakam, 2015).

A well-known cultural observer, Dr. Umar Khayam (alm), stated that this Lebaran tradition was a breakthrough acculturation of Javanese and Islamic culture. The wisdom of the ulama in Java was able to combine the two cultures for the sake of harmony and prosperity of the people. Finally, the Lebaran tradition extends to all parts of Indonesia, and involves residents of various religions. To find out the acculturation of the two cultures, we look at the profile of Islamic culture globallyfirst. In Islamic countries in the Middle East and Asia (besides Indonesia), after Muslims performing Eid prayers there is no tradition of mass shaking hands to forgive one another. There are only a little people who shook hands sporadically as a sign of intimacy (Husna, 2019).

The tradition of halal bi halal is associated with silaturrahim. The most concrete evidence of silaturrahim is a sincere visit and gift. Silaturrahim is not just repaying the kindness of others, but also responding to the ugliness of others with kindness or reconnecting with people who cut ties with those concerned. This is in accordance with the Prophet's hadis (Zulfikar, 2018).

$$
\text { ليس الواصل بلمافافئ و لكن الواصل الذي اذا قطعت رمه وصلها. }
$$

It is not the person who is a friend of love (bersilaturrahim) who is returning a visit or a gift, but the person who is in love (bersilaturrahim) is the one who connects the case that is broken.

From some traditions above, it can be known that there are various kinds and various forms of tradition that exist in Indonesia. Among these are the products of the dialectics between religion and culture, among them are also the other interpretations of the way of worship, such as the celebration of diverse maulids in each region.

The tradition was passed down from the ancestors of Indonesian people until they did not know the ideological, philosophical or historical foundation that was 
made the tradition was emerged and developed in society. They also do not know whether in the Qur'an there is an argument that explains their habits. Because they are used to doing this in accordance with the tradition of practice, even though there is an argument that can be used as a foothold. However, the arguments in the level of practice are not in line with the meaning of the underlying arguments directly. They develop according to the culture and tradition of the people surround them. So, at the end of this paper, the author reiterates that living Hadis is a lifestyle of Indonesian people.

\section{Conclusion}

Society and culture are two inseparable entities. There is no society without culture. There is also no culture without a society in it. In Indonesia, Islamic teachings do not come to an empty space. Islamic teachings come to people who already have a culture. Thus, the cultural approach used by preachers of Islam was the most appropriate approach. Moreover, there is a spirit that breathes the Qur'an and the Hadis in it. Therefore, our job as a young generation is to preserve it so as not to be eroded by the current of globalization.

\section{REFERENCES}

Aizid, R. 2016. Sejarah Islam Nusantara; Dari Analisis Historis hingga Arkeologis tentang Penyebaran Islam di Nusantara (First Edit). Diva Press.

al-Muqri'. 1996. Ahadith fi Dhamm al-Kalam wa Ahlih (first edit). Dar al-Atlas.

Anies, M. 2009. Tahlil dan Kenduri; Tradisi Santri dan Kiai (First Edit). Pustaka Pesantren.

Aziz, A. 2019. Khazanah Hadis di Indonesia. Guepedia.

Aziz, D. K. 2015. Akulturasi islam dan budaya jawa. Fikrah, I(2), 253-286.

Badri Khaeruman. 2010. Ulum al-Hadis (First Edit). Pustaka Setia.

Fitriah, A. 2013. Pemikiran Abdurrahman Wahid Tentang Pribumisasi Islam. Teosofi; Jurnal Tasawuf Dan Pemikiran Islam, 3(1).

Hakam, S. 2015. Halal Bi Halal, a Festival of Idul Fitri and It'S Relation With the History of Islamization in Java. Epistemé: Jurnal Pengembangan Ilmu Keislaman, 10(2). https://doi.org/10.21274/epis.2015.10.2.385-404 
Hanif, A. 2016. Tradisi Peringatan Haul Dalam Pendekatan Sosiologi Pengetahuan Peter L. Berger. Dialogia, 13(1), 49-58.

Husna, M. 2019. Halal Bihalal Dalam Perspektif Adat Dan Syariat. Perada, 2(1), 45-56. https://doi.org/10.35961/perada.v2i1.29

HS, Muhammad Alwi, and Nur Hamid. 2019. "Relasi Kelisanan Al-Qur'an Dan Pancasila Dalam Upaya Menjaga Dan Mengembangkan Identitas Islam Indonesia." International Journal Ihya' 'Ulum Al-Din 21(1): 17-38. http://journal.walisongo.ac.id/index.php/ihya/article/view/4833.

Idris, A. F. 2017. Memahami Kembali Pemaknaan Hadis Qudsi. International Journal Ihya' 'Ulum Al-Din, 18(2), 133. https://doi.org/10.21580/ihya.17.2.1734

Jati, W. R. 2013. Tradisi, Sunnah dan Bid'ah: Analisa Barzanji dalam Perspektif Cultural Studies. El-HARAKAH (TERAKREDITASI), 14(2), 226-242. https://doi.org/10.18860/el.v14i2.2315

Librianti, E. O. I. 2019. Dialektika Islam dan Budaya: Dakwah Kultural Nahdlatul Ulama. Ajiqs, 1(1).

Mustamar, M. (n.d.). al-Muqtatafat li Ahl al-Bidayat. PP. Sabilur Rasyad.

Nadia, Z. 2016. Tradisi Maulid Pada Masyarakat Mlangi Yogyakarta. ESENSIA: $\begin{array}{llll}\text { Jurnal Ilmu-Ilmu Ushuluddin, } & \text { 12(2), } 367 .\end{array}$ https://doi.org/10.14421/esensia.v12i2.718

Qomar, M. 2016. Islam Nusantara: Sebuah Alternatif Model Pemikiran, Pemahaman, Dan Pengamalan Islam. El-HARAKAH (TERAKREDITASI), $17(2)$, https://doi.org/10.18860/el.v17i2.3345

Rodin, R. 2013. Tradisi Tahlilan Dan Yasinan. IBDA' : Jurnal Kajian Islam Dan Budaya, 11(1), 76-87.https://doi.org/10.24090/ibda.v1 1i1.69

Suparjo, S. 1970. Islam dan Budaya: Strategi Kultural Walisongo dalam Membangun Masyarakat Muslim Indonesia. KOMUNIKA: Jurnal Dakwah Dan Komunikasi, 2(2), 178-193. https://doi.org/10.24090/komunika.v2i2.100

Suryadi. 2007. Dari Living Sunnah ke Living Hadis. In S. Syamsuddin (Ed.), Metodologi Peneltian Living Qur'an dan Hadis (First Edit). Teras.

Suryadilaga, M. A. 2007. Model-Model Living Hadis. In Metodologi Peneltian Living Qur'an dan Hadis (First Edit). Teras.

UINSA, L. T. M. al-J. 2020. Adab al-Talibin Fi Ta'lim Sayyid al-Mursalin (cetakan ke). Ma'had al-Jami' ah UINSA. 
Wahid, A. (2012). Tuhan Tidak Perlu Dibela (Second Edi). LKiS.

Warsino, A. 2017. Tradisi Tahlilan Upaya Menyambung Silaturahmi. Ri'ayah, 02(02), 69-79.

Wasid. 2010. Gus Dur Sang Guru Bangsa; Pergolakan Islam, Kemanusiaan, dan Kebangsaan (First Edit). interpena.

Wijaya, A. 2011. Menusantarakan Islam; Menelusuri Jejak Pergumulan Islam yang Tak Kunjung Usai di Nusantara. Nadi Pustaka.

Zuhri, S. and S. K. D. 2018. Living Hadis; Praktik, Resepsi, Teks, dan Transmisi (first edit). Q-Media.

Zulfikar, E. 2018. Tradisi Halal Bihalal dalam Perspektif Al-Qurâ€TMan dan Hadis. Jurnal Online Studi Al-Qur'an, 14(2), 127-150. https://doi.org/10.21009/jsq.014.2.03. 